\title{
Endothelin-1 receptor antagonists prevent the development of pulmonary emphysema in rats
}

\author{
Y. Chen*, , M. Hanaoka*, Y. Droma*, P. Chen\#, N.F. Voelkel" and K. Kubo*
}

ABSTRACT: We hypothesised that endothelin (ET)-1 plays an important role in the pathogenesis of emphysema. We attempted to apply ET-1 receptor antagonists to demonstrate and further elucidate the molecular pathogenesis pathways through which ET-1 may cause emphysematous changes.

Sprague-Dawley rats were divided into four groups: control, cigarette smoke extract (CSE), CSE $+B Q-123$ (a selective endothelin receptor type $A\left(E T_{A}\right)$ antagonist) and $C S E+$ bosentan (a mixed $E T_{A} / E T_{B}$ receptor antagonist). The CSE was injected intraperitoneally once a week for 3 weeks, and BQ-123 or bosentan was administered daily for the same duration. The expression of $\mathrm{ET}_{\mathrm{A}}$ receptor, apoptosis index, caspase-3 activity, matrix metalloproteinase (MMP)-2 and MMP-9 activity, and tumour necrosis factor (TNF)- $\alpha$ and interleukin (IL)-1及 concentrations were measured in the lung tissue. The ET-1 levels and antioxidant activity were measured in the serum.

Both BQ-123 and bosentan prevented the development of CSE-induced emphysema, blocked the expression of $\mathrm{ET}_{\mathrm{A}}$ receptor, inhibited pulmonary apoptosis, inactivated MMP-2 and MMP-9 activities in the lung tissues, reduced the concentrations of inflammatory cytokines TNF- $\alpha$ and IL$1 \beta$, and improved the biological antioxidant activity in the serum.

Emphysema development is suppressed by ET-1 receptor antagonists. ET-1 may cause emphysematous changes through molecular pathogenesis pathways involving apoptosis, proteinase and antiproteinase imbalance, inflammation and oxidative stress.

KEYWORDS: Apoptosis, emphysema, endothelin-1 receptor, inflammatory cytokine, matrix metalloproteinase, oxidative stress

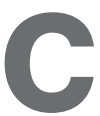
hronic obstructive pulmonary disease (COPD) is a widely prevalent condition usually associated with cigarette smoking, which is by far the most important risk factor for COPD [1]. The 2002 World Health Report from the World Health Organization listed COPD as the fifth leading cause of death worldwide after heart disease, stroke, lower respiratory tract infections and HIV / AIDS [2]. Pulmonary emphysema is one of the major pathological manifestations of COPD and is characterised by abnormal, permanent airspace enlargement beyond the terminal bronchioles accompanied by alveolar wall destruction [1]. The most accepted theories for the pathogenesis of emphysema involve apoptosis [3], proteinase and antiproteinase imbalance [4], chronic inflammation [5] and oxidative stress [6].

Endothelin (ET)-1 is a peptide produced primarily by vascular endothelial cells and is characterised as a powerful smooth muscle vasoconstrictor and mitogen [7]. ET-1 binds to two types of receptors, $\mathrm{ET}_{\mathrm{A}}$ and $\mathrm{ET}_{\mathrm{B}}$ : $\mathrm{ET}_{\mathrm{A}}$ receptors are found on smooth muscle cells and mediate contraction, whereas $\mathrm{ET}_{\mathrm{B}}$ receptors are localised on endothelial cells and smooth muscle cells and mediate vasodilatation via nitric oxide generation [8]. The effects of ET-1 include vasoconstriction, vascular hypertrophy [7], cell proliferation [9] and inflammation [10], and ET-1 may regulate apoptosis. However, whether ET-1 induces or suppresses apoptosis appears to depend on cell type and the cell-specific expression of $\mathrm{ET}_{\mathrm{A}}$ versus $\mathrm{ET}_{\mathrm{B}}$ receptors [11-13].

The ET family of proteins has been found to be involved in multiple physiological functions relating to the respiratory system [14]. In addition, this family has been implicated in the pathogenesis of lung diseases [15]; ET-1 levels were shown to be significantly increased in patients with COPD and asthma [16]. WRIGHT et al. [17] demonstrated that cigarette smoke exposure increases ET expression

\section{AFFILIATIONS}

*First Dept of Medicine, Shinshu University School of Medicine, Matsumoto, Japan,

\#Division of Respiratory Disease, Dept of Internal Medicine, The Second Xiangya Hospital, CentralSouth University, Changsha, Hunan, China, and

"Victoria Johnson Center for Obstructive Lung Diseases, Virginia Commonwealth University, Richmond, VA, USA.

\section{CORRESPONDENCE}

M. Hanaoka

First Dept of Medicine

Shinshu University School of

Medicine

3-1-1 Asahi

Matsumoto 390-8621

Japan

E-mail: masayuki@shinshu-u.ac.jp

Received:

Jan 082009

Accepted after revision:

Oct 262009

First published online:

Nov 062009 
in small intrapulmonary arteries. HOCHER et al. [18] found evidence that the over-expression of ET-1 may be a central event in pulmonary fibrosis and chronic lung inflammation. Moreover, ET-1 receptor antagonists have been established as a first-line option for the majority of patients with pulmonary arterial hypertension [19]. We hypothesised that ET-1 plays an important role in the pathogenesis of COPD. We attempted to apply ET-1 receptor antagonists, including BQ-123, a selective $\mathrm{ET}_{\mathrm{A}}$ antagonist, and bosentan, a mixed $\mathrm{ET}_{\mathrm{A}} / \mathrm{ET}_{\mathrm{B}}$ receptor antagonist, to demonstrate our hypothesis and further elucidate the molecular pathogenesis pathways through which ET-1 may cause emphysematous changes in the lungs of rats upon exposure to cigarette smoke extract (CSE).

\section{MATERIALS AND METHODS \\ Preparation of CSE}

The CSE was prepared by a technique described previously [20]. Briefly, one cigarette (Marlboro; Philip Morris Companies Inc., New York, NY, USA) was burned and the smoke passed through a Cambridge filter to remove particles and bacteria to a vessel containing PBS (1 mL per cigarette) using a vacuum pump. The $\mathrm{pH}$ of CSE-PBS solution was 5.2-5.3 and this solution was prepared fresh for each injection.

\section{Experimental protocol}

The experimental protocol was approved by the Animal Care and Use Committee of Shinshu University and performed according to the Helsinki convention for the use and care of animals. 6-week-old male Sprague-Dawley rats (weight range 200-250 g) were randomly selected and divided into four groups: control, CSE, CSE+BQ-123 and CSE+bosentan ( $n=6$ each group). The total experimental period was three weeks. The control group was injected intraperitoneally with $1 \mathrm{~mL}$ vehicle (normal saline) and the CSE group with $1 \mathrm{~mL}$ CSE-PBS on day 1, 8 and 15. The CSE+BQ-123 and CSE+bosentan groups were injected intraperitoneally with $1 \mathrm{~mL}$ of CSE on day 1,8 and 15 along with BQ-123 or bosentan, respectively. The BQ-123 was injected intraperitoneally daily $\left(1 \mathrm{mg} \cdot \mathrm{kg}^{-1} \cdot\right.$ day $\left.^{-1}\right)$ for 21 days. The BQ-123 (Peptides International Inc., Louisville, KY, USA) was dissolved in 5\% dimethyl sulphoxide (DMSO) according to manufacturer's instruction and then diluted in PBS to obtain a BQ-123 solution containing $0.5 \%$ DMSO. The concentration of $0.5 \%$ DMSO has been proved to be harmless in animals with i.p. injection [21, 22]. Bosentan (Actelion Pharmaceuticals Japan Ltd, Tokyo, Japan) was prepared fresh each week as a suspension in 5\% arabic gum and administered $\left(100 \mathrm{mg} \cdot \mathrm{kg}^{-1} \cdot \mathrm{day}^{-1}\right)$ daily via gastric gavage for 21 days. The concentration of gum arabic did not exceed 5\%, which has been shown to have no effect per se on the property and action of the drug [23]. Both BQ-123 and bosentan have been frequently used in studies of pulmonary hypertension in rat models [19] and the dosages were suggested in previous experiments elsewhere [24, 25] with no adverse effects on rats at the current dosages [25]. The administration of BQ-123 or bosentan was started the same day with the first CSE injection. All rats were in the same living environment for the experimental period. On day 21, the rats were sacrificed and the blood samples and lung tissues were obtained as described below.

\section{Sampling the blood and lung tissue}

All rats were anaesthetised with pentobarbital intraperitoneally. The blood samples were taken from the inferior vena cava via the opened chest and collected in polypropylene tubes containing a clot activator. The samples were centrifuged within $1 \mathrm{~h}$ at $3000 \times g$ for $15 \mathrm{~min}$. The tissue processing was performed as previously described [20]. Lung tissue homogenates were prepared [20] and the levels of protein in the supernatant were determined using the bicinchoninic acid protein assay (Pierce Biotechnology, Inc., Rockford, IL, USA). Serum and supernatants were stored at $-70^{\circ} \mathrm{C}$ until they were used.

\section{Morphometry}

Lung sections in 3.5- $\mu \mathrm{m}$ thick were stained with haematoxylin and eosin. Emphysema was quantified by measuring the mean linear intercept (MLI) [20] and determining the destructive index (DI) [20]. The morphological assessment was performed on coded samples.

\section{ET-1 in serum}

The levels of ET-1 in serum were measured in duplicate by ELISA (ET-1 EIA kit; Phoenix Pharmaceuticals, Inc., Burlingame, CA, USA) according to the manufacturer's instructions.

\section{Examination of $E T_{A}$ receptor in the lung tissues of rats Immunohistochemistry for $E T_{A}$ receptor in lung tissues}

The $\mathrm{ET}_{\mathrm{A}}$ receptors in the lungs of rats were examined by immunohistochemistry (biotin-streptavidin amplification system) of paraffin sections using a rabbit anti-rat $\mathrm{ET}_{\mathrm{A}}$ receptor polyclonal antibody (LifeSpan BioSciences, Seattle, WA, USA) [20]. The optimal dilution of primary antibody (1:100) was suggested by the manufacturer's instructions. The intensity of cytoplasmic $\mathrm{ET}_{\mathrm{A}}$ receptor immunostaining was evaluated semi-quantitatively by a four-grade score of the number of stained cells ( 0 corresponding 0,1 to $1-30,2$ to $31-60,3$ to $61-$ 90 , and 4 to $>90$ stained cells in one of 10 observed areas per section) as suggested previously [26].

\section{Quantifying the expression of $E T_{A}$ receptor in lung tissues}

The relative quantity of $\mathrm{ET}_{\mathrm{A}}$ receptors in the lung tissues was assessed by Western blotting [20]. Approximately $60 \mu \mathrm{g}$ of total protein extracts in lung homogenates were separated on NuPAGE $_{\circledast}$ Novex 4-12\% Bis-Tris Gel (Invitrogen, Carlsbad, CA, USA) and the protein bands were electrically transferred onto polyvinylidene difluoride (PVDF) membranes (Invitrolon ${ }^{\mathrm{TM}}$ PVDF, Invitrogen). After blocking with 5\% skimmed milk in PBS ( $\mathrm{pH}$ 7.4) containing $0.1 \%$ Tween 20 (PBST) for $1 \mathrm{~h}$ at room temperature, the membranes were incubated with the rabbit antirat $\mathrm{ET}_{\mathrm{A}}$ receptor polyclonal antibody (1:250; LifeSpan BioSciences) overnight at $4^{\circ} \mathrm{C}$. The membranes were washed with PBST and then incubated with secondary anti-rabbit antibody (1:1,000; R\&D Systems, Minneapolis, MN, USA) for $1 \mathrm{~h}$ at room temperature. The bands were developed using chemiluminescence (PerkinElmer Life and Analytical Sciences, Inc., Waltham, MA, USA). Band detection was performed using Quantity One 1-D Analysis Software (Bio-Rad Laboratories, Hercules, CA, USA).

\section{Evaluation of apoptosis}

Measurement of the apoptotic index

Terminal deoxynucleotidyl transferase-mediated dUTP nick endlabeling (TUNEL) was performed to label the DNA-damaged 
cells in the lungs of experimental rats using the TACS 2 TdT DAB kit (Trevigen, Gaithersburg, MD, USA) according to the manufacturer's instruction. The apoptotic index (AI) was calculated as the percentage of TUNEL-positive (TUNEL+) nuclei in $>3,000$ nuclei randomly counted for each lung at $\times 400$ magnification [20].

\section{Immunohistochemistry for activated caspase-3}

Activated caspase-3, a marker of apoptosis, was assessed in paraffin-embedded lung tissues using cleaved caspase-3-specific rabbit polyclonal antibody (Cell Signaling Technology, Inc., Danvers, MA, USA), according to the manufacturer's instructions.

\section{Quantifying casapase-3 in lung tissue}

The relative quantity of caspase- 3 protein in the lung tissues was assessed by Western blotting [20]. The following antibodies were used: cleaved caspase-3-specific rabbit polyclonal antibody (dilution in 1:500; Cell Signaling Technology, Inc.) and secondary anti-rabbit antibody (dilution in 1:1,000; R\&D Systems). Detection was performed with Quantity One 1-D Analysis Software (Bio-Rad Laboratories).

\section{Measurement of matrix metalloproteinase-2 and -9 activities by gelatin zymography}

To observe the status of the proteinase and antiproteinase balance, matrix metalloproteinase (MMP)-2 and MMP-9 activities were determined using 10\% zymogram (gelatin) gels (Invitrogen). Proteolysis bands were visualised and quantified using Printgraph (ATTO, Tokyo, Japan).

\section{Measurements of tumour necrosis factor- $\alpha$ and interleukin- $1 \beta$ concentrations in lung tissues}

To observe the inflammatory condition of the rats, tumour necrosis factor (TNF)- $\alpha$ and interleukin (IL)- $1 \beta$ concentrations were measured in the supernatants of lung homogenates using commercially available ELISA kits (Quantikine ${ }^{\circledR}$ Rat TNF- $\alpha$ kit and Quantikine ${ }^{\circledR}$ Rat IL-1 $\beta$ kit; R\&D Systems) according to the manufacturer's instructions.

\section{Measurement of antioxidant activity in blood}

Serum antioxidant activity was measured by the bioantioxidant power (BAP) test using the Free Radical Elective Evaluation FRAS4 system (Diacron International s.r.l., Grosseto, Italy) according to the analysis procedure in the manufacturer's instructions. Briefly, $10 \mu \mathrm{L}$ of serum was dissolved in a solution previously prepared by mixing $\mathrm{FeCl}_{3}$ with a thiocyanate derivative solution. After a 5-min incubation at $37^{\circ} \mathrm{C}$, the solution lost colour, and the intensity of the chromic change was directly proportional to the reductive activity. Photometric readings assessed the intensity of decolouration to evaluate the effective reduction activity or antioxidant potential. A lyophilised human control serum with known antioxidant activity $\left(\mu \mathrm{mol} \cdot \mathrm{L}^{-1}\right)$ was used to periodically calibrate the FRAS4 system. The results of the BAP test provided the serum biological antioxidant potential, expressed in $\mu \mathrm{mol} \cdot \mathrm{L}^{-1}$.

\section{Statistical analysis}

A software package (SPSS 15.0, SPSS Inc., Chicago, IL, USA) was used to perform all statistical analyses. Continuous data were expressed as mean $\pm \mathrm{SD}$. Any differences among the four groups were evaluated by one-way ANOVA. The Pearson
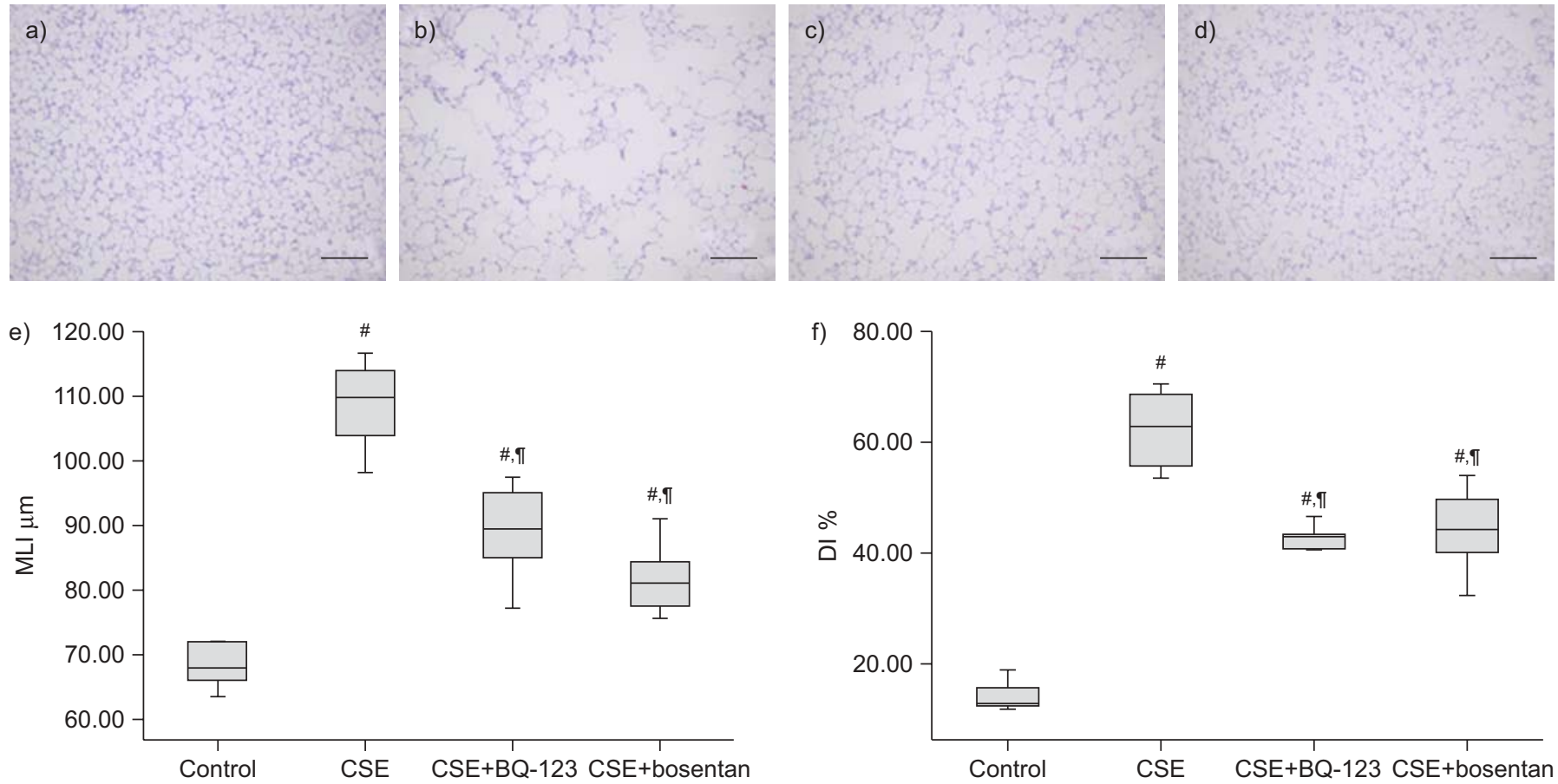

FIGURE 1. Histological examinations. Photomicrographs of lung tissues stained with haematoxylin and eosin: a) control group, b) cigarette smoke extract (CSE) group, c) $C S E+B Q-123$ group, and d) CSE+bosentan group. Scale bars $=50 \mu \mathrm{m}$. Morphometric measurements of the e) mean linear intercept (MLI) and f) destructive index (DI) in the four groups. Data are presented as mean \pm SD and range. ${ }^{\#}: p<0.0001$ versus control group; ${ }^{\top}: p<0.0001$ versus CSE group. 


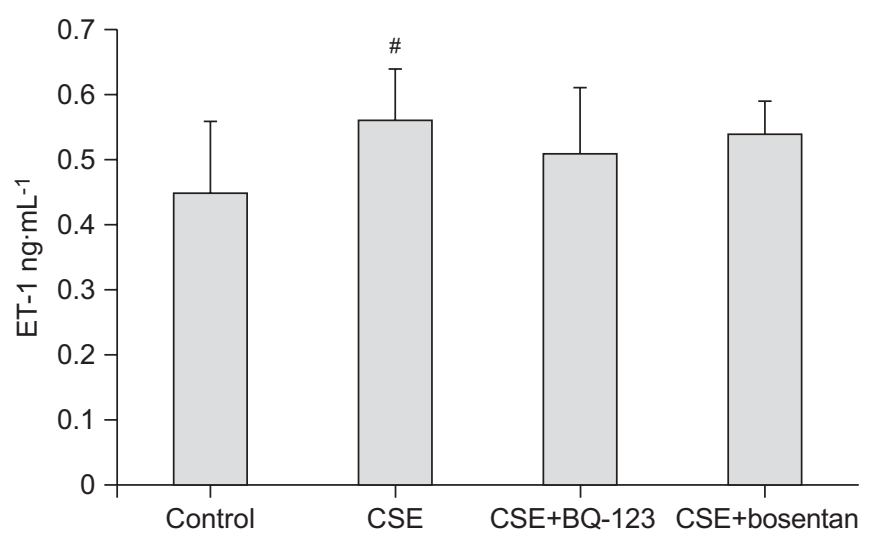

FIGURE 2. Endothelin (ET)-1 concentrations in serum. Data are presented as mean \pm SD. CSE: cigarette smoke extract. ${ }^{*}: p=0.023$ versus controls

correlation was used to separately analyse the correlations between $\mathrm{AI}$ and TNF- $\alpha$ or IL-1 $\beta$ concentrations. A p-value $<0.05$ was considered significant.

\section{RESULTS}

\section{Histological examinations}

First, we established that the i.p. injection of CSE induced emphysema within 3 weeks. Our data confirmed our previous findings [20]. Compared with the normal alveolar architecture of the control group (fig. 1a), the CSE group exhibited lung parenchymal destruction and airspace enlargement (fig. 1b). However, BQ-123 and bosentan markedly suppressed these emphysematous changes (fig. $1 c$ and $d$, respectively).
Quantitatively, the MLI and DI were significantly increased in the CSE group $(108.7 \pm 6.8 \mu \mathrm{m}$ and $62.2 \pm 7.0 \%$, respectively) compared with the control group $(69.8 \pm 6.6 \mu \mathrm{m}, \mathrm{p}<0.0001$; $13.9 \pm 2.7 \%$, $p<0.0001$; fig. $1 \mathrm{e}$ and $\mathrm{f})$. The MLI and DI were significantly reduced in the CSE+BQ-123 $(89.0 \pm 7.4 \mu \mathrm{m}$ and $41.5 \% \pm 4.5 \%$, respectively) and CSE+bosentan groups $(81.9 \pm$ $6.1 \mu \mathrm{m}$ and $44.0 \pm 8.5 \%$, respectively) compared with the CSE group $(\mathrm{p}<0.0001$ and $\mathrm{p}<0.0001$, respectively). There were no significant differences in the MLI and DI between the CSE+BQ123 and CSE+bosentan groups. Because the MLI and DI in the $\mathrm{CSE}+\mathrm{BQ}-123$ and CSE+bosentan groups did not completely return to the normal values of the control group $(p<0.0001$ and $p=0.005$, respectively), the ET- 1 receptor antagonists did not provide a complete suppression of the emphysematous changes.

\section{Serum ET-1 concentrations}

As shown in figure 2, the concentration of serum ET-1 was significantly increased in the CSE group $\left(0.56 \pm 0.08 \mathrm{ng} \cdot \mathrm{mL}^{-1}\right)$ compared to controls $\left(0.45 \pm 0.11 \mathrm{ng} \cdot \mathrm{mL}^{-1} ; \mathrm{p}=0.023\right)$. However, treatment with BQ-123 and bosentan did not change the serum ET-1 concentration of rats injected with CSE $\left(0.51 \pm 0.10 \mathrm{ng} \cdot \mathrm{mL}^{-1}\right.$ and $0.54 \pm 0.05 \mathrm{ng} \cdot \mathrm{mL}^{-1}$, respectively; $\mathrm{p}>0.05$ versus CSE). There was no significant difference in serum ET-1 between CSE+BQ-123 and CSE+bosentan groups.

\section{The expression of $E T_{A}$ receptor in the lung tissues of rats} Immunohistochemistry for $E T_{A}$ receptor

The intensity of $\mathrm{ET}_{\mathrm{A}}$ receptor immunostaining in the lungs was in grade 1 in control rats (fig. 3a), but enhanced to grade 3 in rats with injection of CSE (fig. 3b). However, the intensity of $\mathrm{ET}_{\mathrm{A}}$ receptor immunostaining was kept in grade 1 in both
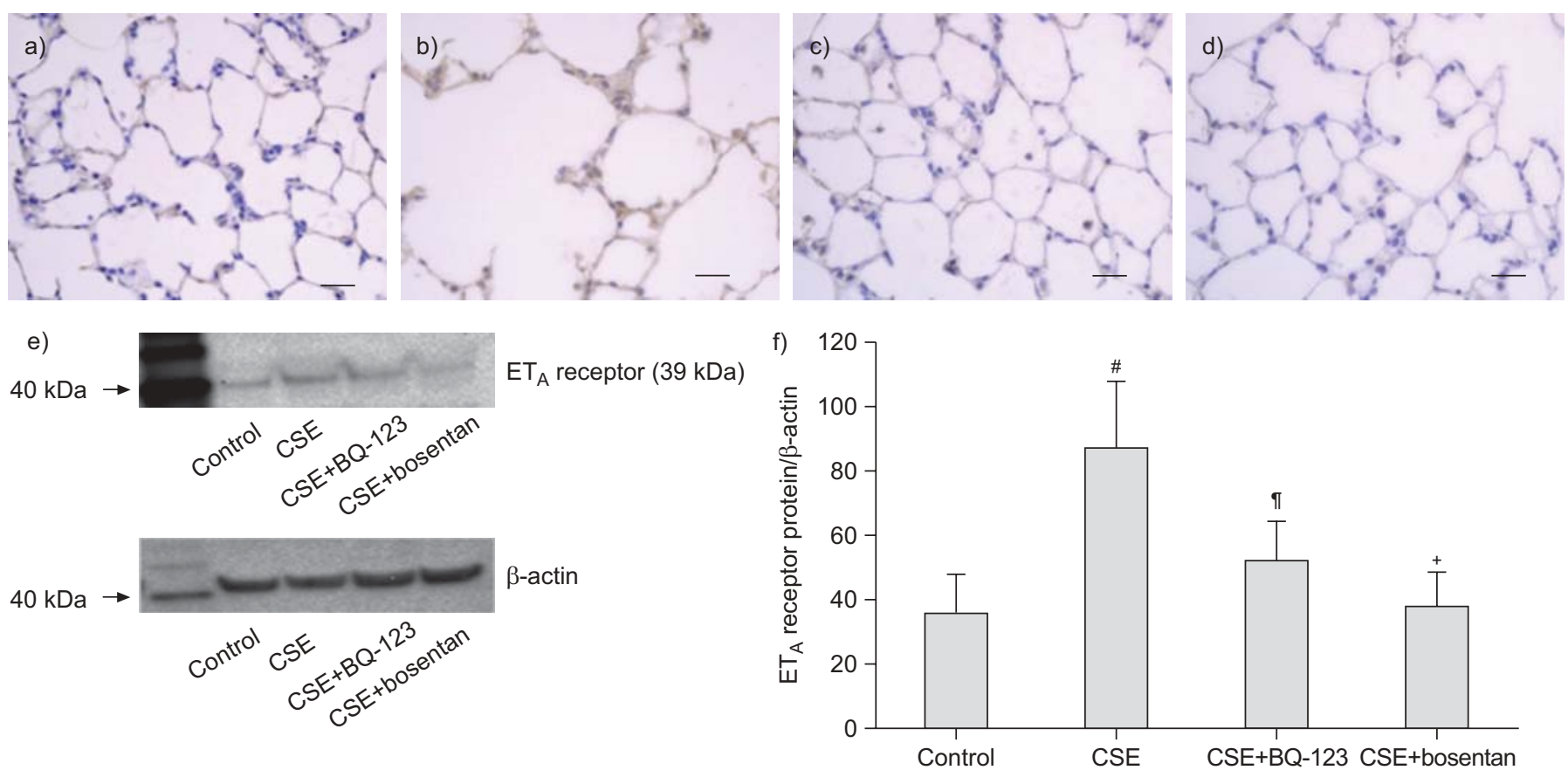

FIGURE 3. Detection of endothelin type $A\left(E T_{A}\right)$ receptor in the lung tissues of rats. Immunohistochemistry for $\mathrm{ET}_{\mathrm{A}}$ receptor. The intensity of $\mathrm{ET}_{\mathrm{A}}$ receptor immunostaining in the lung was in grade 1 in control rats (a), but increased to grade 3 in rats with injection of cigarette smoke extract (CSE) (b). The intensity of $\mathrm{ET}_{\mathrm{A}}$ receptor immunostaining in the lung was in grade 1 in both CSE+BQ-123 (c) and CSE+bosentan groups (d). Scale bars=50 $\mu \mathrm{m}$. e) Western blot for ETA receptor in the lung tissues of rats and f) the density of $E T_{A}$ receptor relative to $\beta$-actin in the four experimental rat groups (mean \pm SD). ${ }^{\#}: p<0.0001$ versus control group; ${ }^{\circ}: p=0.005$ in $C S E+B Q-123$ group versus $C S E$ group; ${ }^{+}$: $p<0.0001$ in CSE+bosentan group versus CSE group. 

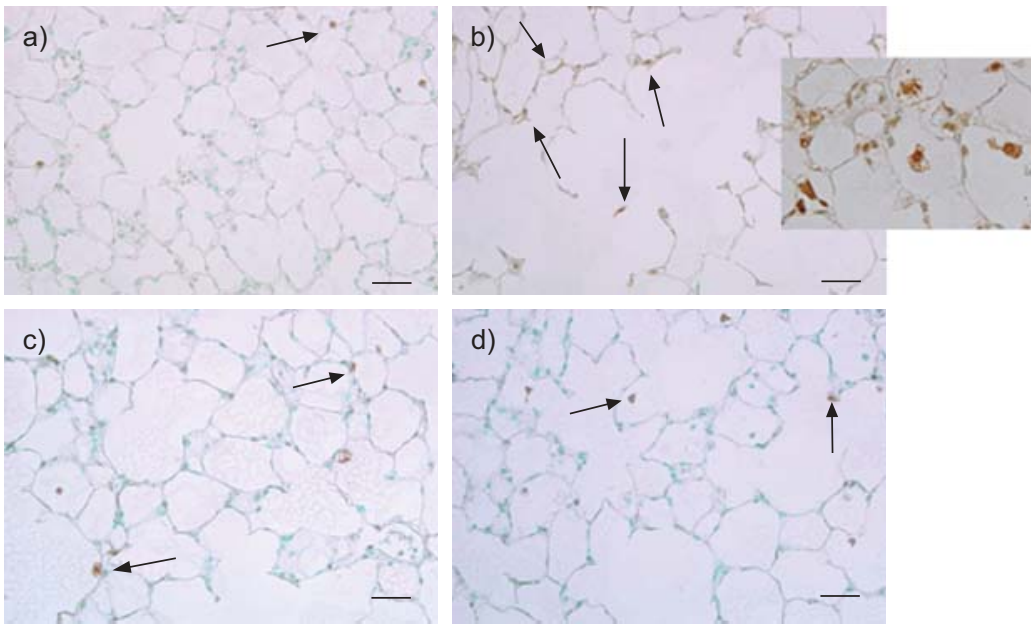

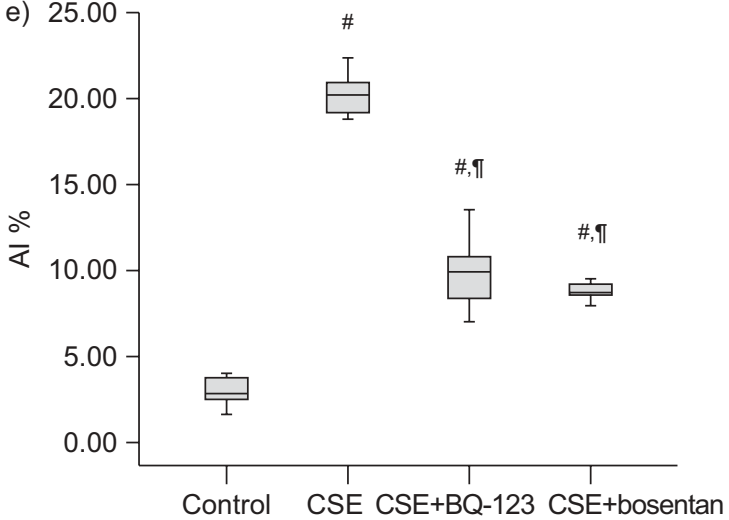

FIGURE 4. Apoptosis in the lung tissues of rats. Apoptotic nuclei detected by terminal deoxynucleotidyl transferase-mediated dUTP nick end-labeling (TUNEL) staining TUNEL+ cells were abundantly distributed (arrows) in the alveolar septa in the lungs of cigarette smoke extract (CSE)-challenged rats (b) but were sporadically distributed (arrows) in the alveolar septa of lungs from the control group (a), CSE+BQ-123 group (c) and CSE+bosentan group (d). Scale bars=50 $\mu \mathrm{m}$. The inserted zoomed photo shows apoptotic epithelial cells. e) Apoptosis index (Al) in the four experimental groups (mean \pm SD). ${ }^{*}$ : $p<0.0001$ versus control group; ${ }^{\circ}$ : $p<0.0001$ versus CSE group.

CSE+BQ-123 (fig. 3c) and CSE+bosentan groups (fig. 3d), suggesting an efficiently inhibitive effect of these endothelin receptor antagonists on $\mathrm{ET}_{\mathrm{A}}$ receptors in the lungs of rats with injection of CSE.

Quantifying the expression of $E T_{A}$ receptor by Western blot Western blotting (fig. 3e) showed that the $\mathrm{ET}_{\mathrm{A}}$ receptor expression was enhanced in the CSE group, but the BQ-123 and bosentan suppressed the enhancement of $\mathrm{ET}_{\mathrm{A}}$ receptor expression in rats injected with CSE. The densitometry analysis showed that the relative density of $\mathrm{ET}_{\mathrm{A}}$ receptor to $\beta$-actin was increased in the CSE rats $(87.6 \pm 20.5 \%)$ compared to that in controls $(36.5 \pm 11.7 \%$; $p<0.0001$ (fig. 3f). However, the relative density was significantly suppressed to $52.5 \pm 12.4 \%$ in CSE+BQ-123 group $(p=0.005)$ and $38.2 \pm 10.9 \%$ in CSE+bosentan group $(p<0.0001)$ compared to that in CSE group (fig. 3f). These results
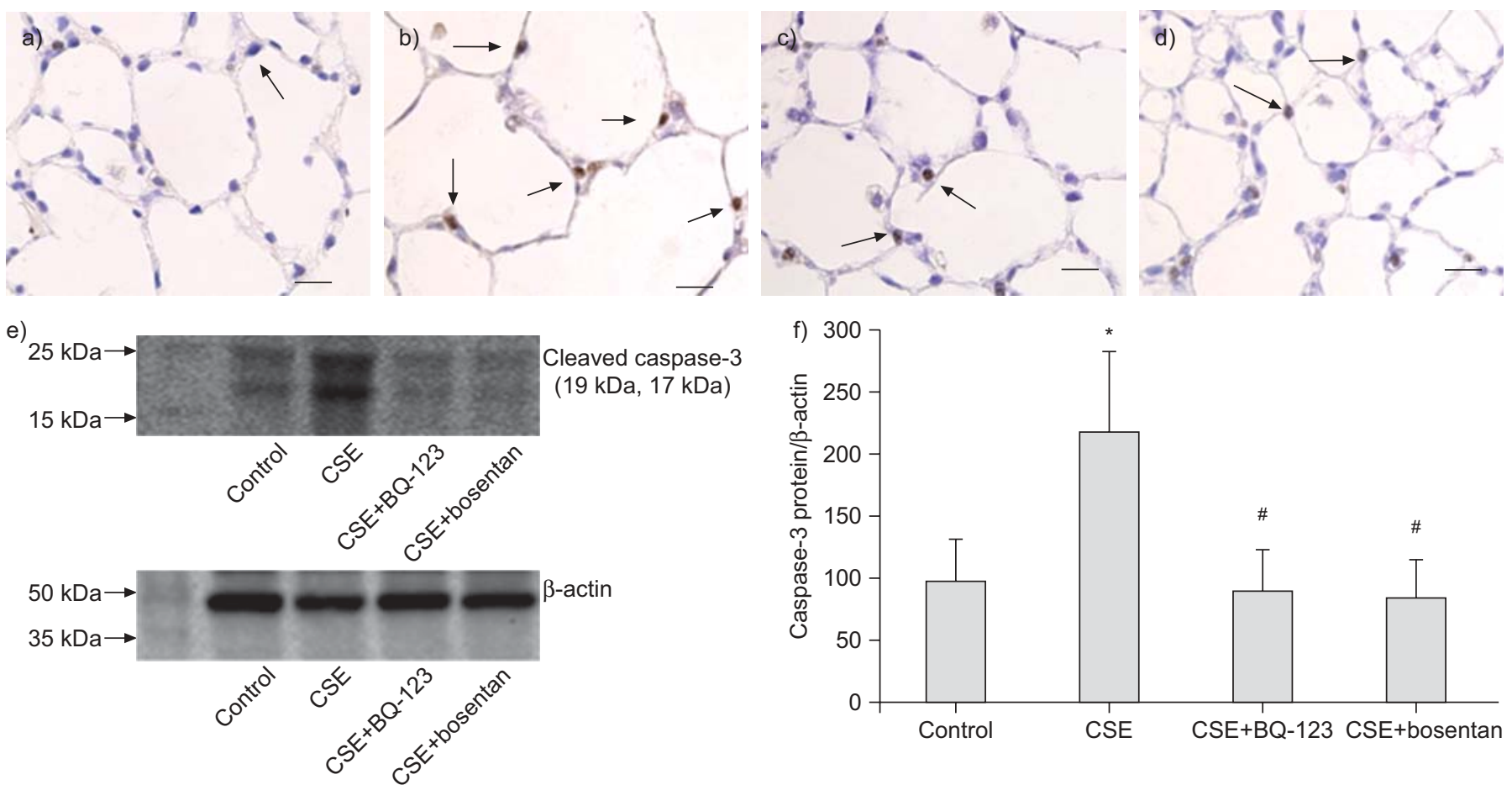

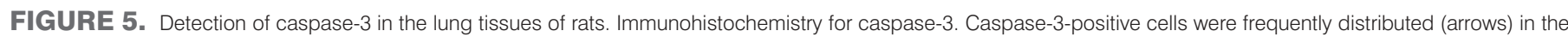

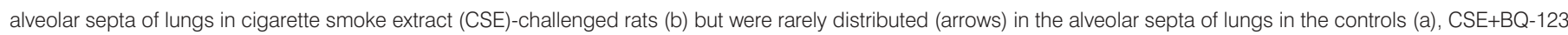

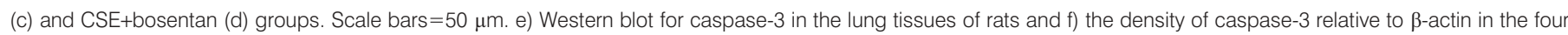
experimental rat groups (mean $\pm \mathrm{SD}$ ). ${ }^{*}: \mathrm{p}<0.05$ versus control group; ${ }^{*}: \mathrm{p}<0.05$ versus CSE group. 
a)
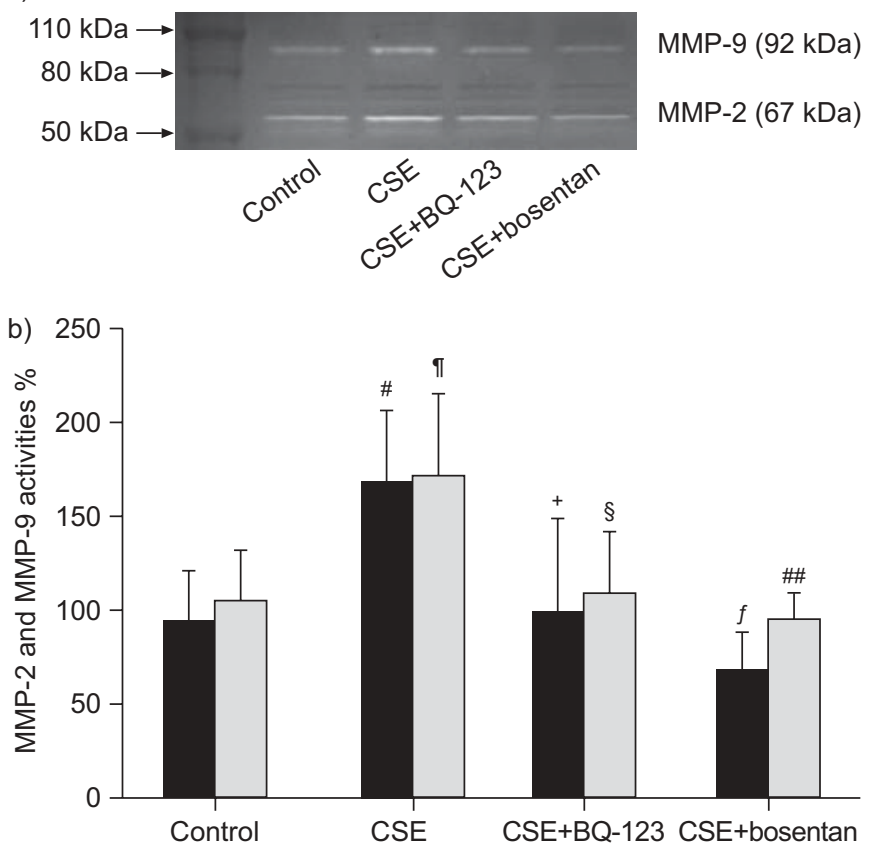

FIGURE 6. Expression of matrix metalloproteinase (MMP)-2 and MMP-9 activities in the lungs of rats. a) Gelatin zymography of lung tissue homogenates showed that endothelin-1 receptor antagonists prevented the increases in MMP-2 and MMP-9 activities in cigarette smoke extract (CSE)-challenged rats. b) Relative density of the MMP-2 ( $\square$ ) and MMP-9 ( $\mathbf{\square})$ activities in the four experimental groups (mean \pm SD). ${ }^{*}: p=0.012$ versus control group; ${ }^{\bullet}: p=0.011$ versus control group; ${ }^{+}$ $p=0.018$ versus CSE group; ${ }^{\S}: p=0.015$ versus CSE group; ${ }^{f}: p=0.002$ versus CSE group; $^{\# \#: ~} p=0.004$ versus CSE group.

suggested that the enhancements of $\mathrm{ET}_{\mathrm{A}}$ receptors in the lungs of CSE rats were effectively inhibited by the BQ-123 and bosentan.

\section{Effects of ET-1 receptor antagonists on apoptosis in emphysematous rat lungs}

TUNEL and Al measurement

As shown in figure 4, TUNEL+ cells were markedly distributed in the peribronchioles, alveolar regions, and the septal areas of the CSE-treated emphysematous lungs (fig. 4b) compared to the lungs of controls (fig. 4a). In contrast, the number of TUNEL+ cells was reduced in the CSE+BQ-123 (fig. 4c) and CSE+bosentan (fig. 4d) groups compared to the CSE group. Quantitatively, the AI was significantly higher in the CSE group $(20.3 \pm 0.9 \%)$ than controls $(2.9 \pm 0.9 \%$; $<0.0001)$, and the AI was significantly reduced in the CSE+BQ-123 $(9.9 \pm 2.3 \% ; \mathrm{p}<0.0001)$ and $\mathrm{CSE}+$ bosentan groups $(8.8 \pm 0.6 \%$; $\mathrm{p}<0.0001$ ) compared to the CSE group (fig. 4e). Because the AI in both intervention groups did not reach the normal values of the controls $(p<0.0001)$, it appears that the ET-1 receptor antagonists inhibited, but did not completely prevent, pulmonary apoptosis. There was no significant difference of the $\mathrm{AI}$ between the CSE+BQ-123 and CSE+bosentan groups.

Immunohistochemistry for activated caspase-3

As shown in figure 5, caspase-3-positive cells were markedly increased in the emphysematous lungs of the CSE group (fig. 5b) compared to the lungs of the controls (fig. 5a). The number of positive cells was reduced in the CSE+BQ-123 (fig. 5c) and CSE+bosentan (fig. 5d) groups compared to the CSE group.

\section{Quantifying caspase-3 in the lung tissues by Western blot}

Figure 5 shows that, compared to the control group, caspase- 3 expression was prominently enhanced in the CSE group, but BQ-123 and bosentan significantly suppressed the caspase-3 enhancement in rats injected with CSE. The density of caspase- 3 relative to $\beta$-actin, as determined by densitometry analysis, showed that the level of cleaved caspase- 3 protein was increased in the CSE rats $(218.2 \pm 64.7 \%)$ compared to controls $(98.2 \pm 34.3 \%$; $\mathrm{p}<0.05)$ (fig. 5f). Both BQ-123 and bosentan markedly inhibited the increase of cleaved caspase-3 in rats injected with CSE (CSE+BQ-123 group: 90.4 $\pm 32.9 \%$; CSE+bosentan group: $84.9 \pm 30.8 \%$; $<<0.05$ compared to CSE) (fig. 5f).

\section{Effects of ET-1 receptor antagonists on MMP-2 and MMP-9 activities in emphysematous rat lungs}

As shown in figure 6, rats injected with CSE exhibited increased MMP-2 and MMP-9 activities in lung tissue homogenates (MMP-2: 172.1 $\pm 43.5 \%$; MMP-9: $168.9 \pm 38.6 \%$ ) compared to controls (MMP-2: 105.5 $\pm 27.1 \%, \mathrm{p}=0.011$; MMP-9: $94.5 \pm 27.1 \%, \mathrm{p}=0.012)$. As expected, both $\mathrm{BQ}-123$ and bosentan significantly reduced the activities of MMP-2 (109.6 $\pm 32.8 \%$, $\mathrm{p}=0.015$ and $95.1 \pm 14.1 \%, \mathrm{p}=0.004$, respectively) and MMP-9 $(99.9 \pm 50.0 \%, p=0.018$ and $68.4 \pm 19.9 \%, p=0.002$, respectively) in rats injected with CSE. There was no significant difference in either the MMP-2 or MMP-9 activity between the CSE+BQ-123 and CSE+bosentan groups.

\section{Effect of ET-1 receptor antagonists on inflammation in rats with emphysema}

The levels of TNF- $\alpha$ and IL-1 $\beta$ were expressed relative to the quantity of homogenate protein $\left(\mathrm{pg} \cdot \mathrm{mg}^{-1}\right)$. As shown in figure $7 a$ and $b, T N F-\alpha$ and IL-1 $\beta$ were significantly increased in the CSE group $\left(11.4 \pm 1.4 \mathrm{pg} \cdot \mathrm{mg}^{-1}\right.$ and $214.4 \pm 52.7 \mathrm{pg} \cdot \mathrm{mg}^{-1}$ respectively) compared to controls $\left(8.3 \pm 1.0 \mathrm{pg} \cdot \mathrm{mg}^{-1}, \mathrm{p}=0.0005\right.$ and $131.4 \pm 36.2 \mathrm{pg} \cdot \mathrm{mg}^{-1}, \mathrm{p}=0.01$, respectively). Both $\mathrm{BQ}-123$ and bosentan suppressed the increase in inflammatory cytokines in rats injected with CSE (CSE+BQ-123: TNF- $\alpha$ $9.0 \pm 1.5 \mathrm{pg} \cdot \mathrm{mg}^{-1}, \quad \mathrm{p}=0.005$ and IL-1 $\beta \quad 132.0 \pm 76.3 \mathrm{pg} \cdot \mathrm{mg}^{-1}$, $\mathrm{p}=0.01 ;$ CSE+bosentan: TNF- $\alpha 8.1 \pm 1.2 \mathrm{pg} \cdot \mathrm{mg}^{-1}, \quad \mathrm{p}=0.0003$ and IL-1 $\beta$ 138.2 $\left.\pm 38.5 \mathrm{pg} \cdot \mathrm{mg}^{-1}, \mathrm{p}=0.02\right)$. In addition, TNF- $\alpha$ and IL-1 $\beta$ in the lungs were positively correlated with the AI $(r=0.693, p=0.001$ and $r=0.555, p=0.009$, respectively) (fig. $7 c$ and $d)$.

\section{Effect of ET-1 receptor antagonists on oxidative stress in rats with emphysema}

The serum antioxidant activity was significantly decreased in the CSE group $\left(1653.4 \pm 504.7 \mu \mathrm{mol} \cdot \mathrm{L}^{-1}\right)$ compared to controls $\left(2438.9 \pm 235.6 \mu \mathrm{mol} \cdot \mathrm{L}^{-1} ; \mathrm{p}=0.001\right)$ (fig. 8). Both $\mathrm{BQ}-123$ and bosentan significantly prevented the decrease in serum antioxidant activity (CSE+BQ-123: $2551.1 \pm 144.8 \mu \mathrm{mol} \cdot \mathrm{L}^{-1}, \mathrm{p}=0.0003$ versus CSE group; CSE+bosentan: $2597.0 \pm 409.8 \mu \mathrm{mol} \cdot \mathrm{L}^{-1}$, $\mathrm{p}=0.0002$ versus CSE group). The serum antioxidant activity in the CSE+BQ-123 and CSE+bosentan groups was statistically similar to that of the control group. There was no significant 

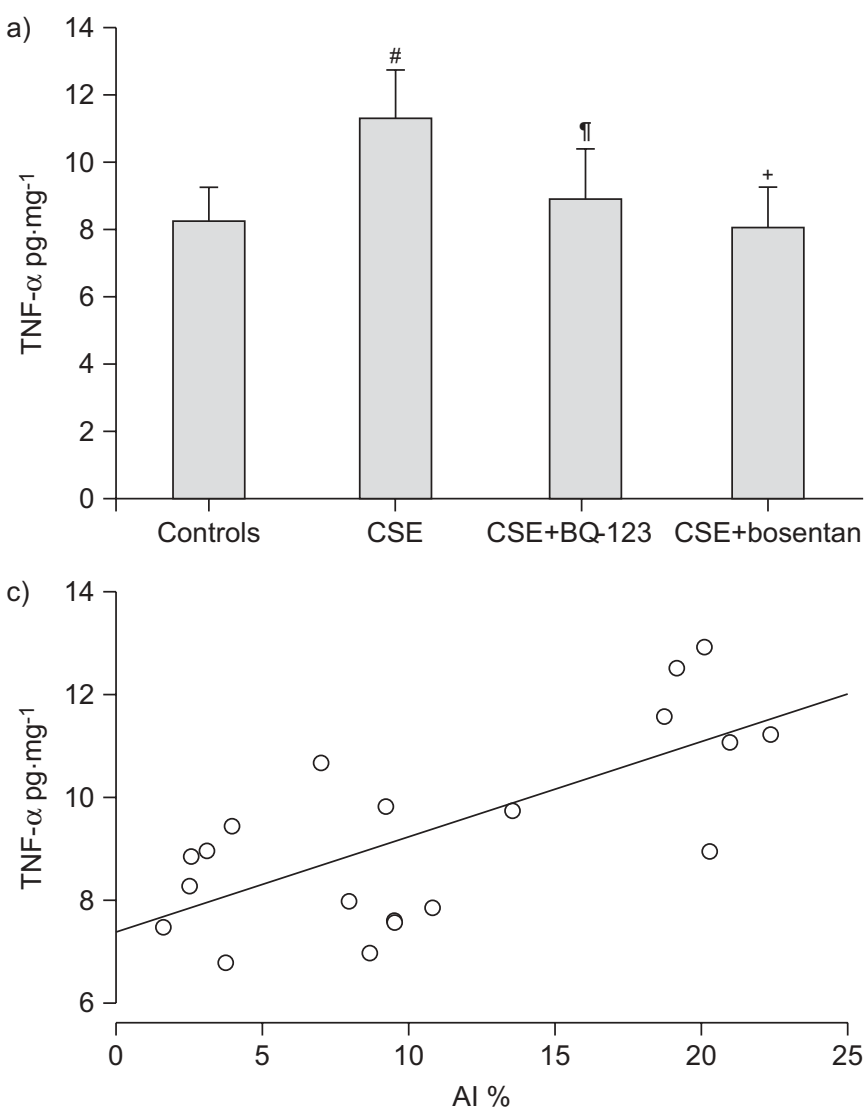
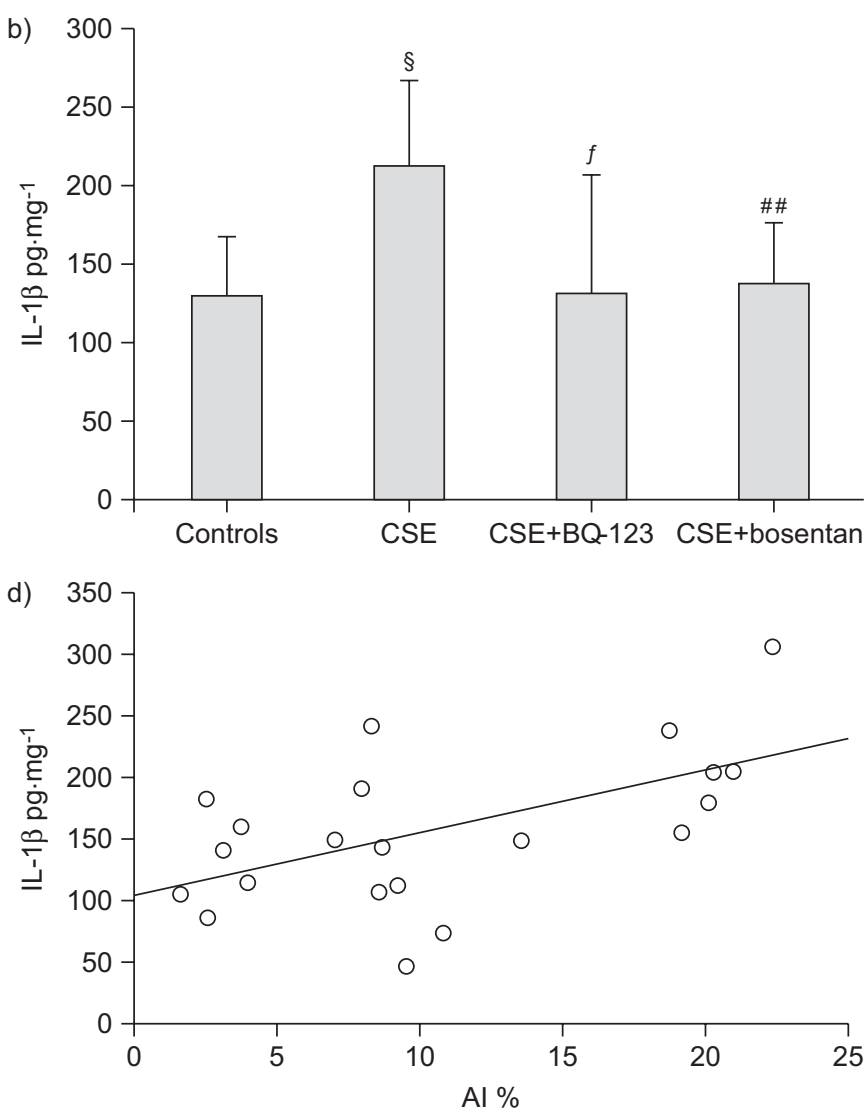

FIGURE 7. Concentrations of tumour necrosis factor (TNF)- $\alpha$ and interleukin (IL)- $1 \beta$ in lung tissues. The levels (mean \pm SD) of a) TNF- $\alpha$ and $b$ ) IL-1 $\beta$ were expressed in relation to the quantity of total protein in the homogenates $\left(\mathrm{pg} \cdot \mathrm{mg}^{-1}\right){ }^{*}: p=0.0005$ versus control group; ${ }^{\circ}: p=0.005$ versus cigarette smoke extract (CSE) group; ${ }^{+}: p=0.0003$ versus CSE group; ${ }^{\text {s: }} p=0.01$ versus control group; ${ }^{f}: p=0.01$ versus CSE group; ${ }^{\# \#: ~} p=0.02$ versus CSE group. The levels of $C$ ) TNF- $\alpha$ and d) IL-1 $\beta$ in the lung tissues were positively correlated with the apoptosis index (Al) $(r=0.693, p=0.001$ and $r=0.555, p=0.009$, respectively).

difference in the serum antioxidant activity between the CSE+BQ123 and CSE+bosentan groups.

\section{DISCUSSION}

The main finding of this study is that intervention with ET-1 receptor antagonists, BQ-123 or bosentan, suppresses the

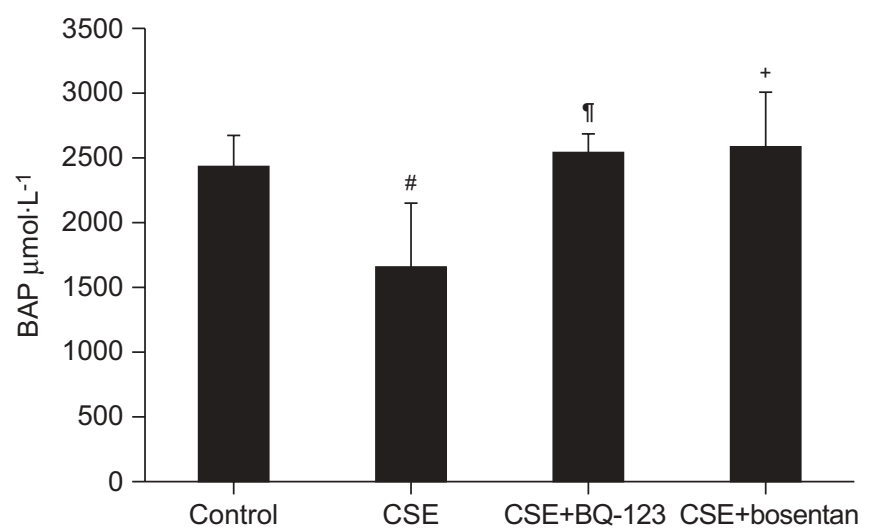

FIGURE 8. Serum antioxidant activity (mean \pm SD) measured by the biological antioxidant power (BAP) test. ${ }^{*}: p=0.001$ versus control group; $": p=0.0003$ versus cigarette smoke extract (CSE) group; ${ }^{+}: p=0.0002$ versus CSE group. development of emphysema induced by CSE challenge. The ET-1 receptor blockers inhibited parenchyma cell apoptosis, and also reduced MMP-2 and MMP-9 activities, decreased inflammatory cytokine levels, and improved the antioxidant activity in CSE-treated rats. All of these evidences demonstrate our hypothesis that ET-1 plays an important role in the pathogenesis of pulmonary emphysema in rats upon exposure to cigarette smoke extract.

The experimental model used in the present study was described previously [27] and successfully replicated and applied to the COPD study in our laboratory recently [20]. The i.p. CSE injection caused enlargement of the alveolar air spaces in rats by $35 \%$ [27] and this model was also replicated in mice [28]. Both confirmed the efficiency and effect of the CSE injection in establishing a smoking-related rodent emphysema model. The mechanism in this novel animal emphysema model is not completely known but thought to be involved with autoimmune mechanism in alveolar septal cell destruction $[29,30]$. It is unclear whether all pathobiologically relevant mechanisms in this model are shared with the conventional model in which cigarette smoke is inhaled over a period of several months. Nevertheless, following i.p. injection of CSE for 3 weeks, rats exhibited pulmonary emphysema pathologically with airspace enlargement and alveolar destruction. 
Probably due to the difference of the metabolic pathway of ET-1 in peripheral circulation from that in lung [19], the increase in serum ET-1 in CSE group was very small $(<20 \%)$ in comparison with the level in controls. However, the expression of $\mathrm{ET}_{\mathrm{A}}$ receptor was markedly enhanced in the lungs of CSEchallenged rats and the $\mathrm{ET}_{\mathrm{A}}$ receptor blockers efficiently prevented the enhancement. It is highly possible that the ET-1 and its receptors are strongly associated with the pathological emphysematous changes induced by CSE injection in rats.

In the CSE-challenged rats, the number of apoptotic cells and level of caspase-3 activity were increased, but this was ameliorated by ET-1 receptor blockers. Apoptosis inhibition by ET-1 receptor blockers is not unprecedented, since SHAW et al. [31] demonstrated that treatment with an $\mathrm{ET}_{\mathrm{A}} / \mathrm{ET}_{\mathrm{B}}$ receptor antagonist reduced the degree of apoptosis observed in the dog lung after ischaemia-reperfusion injury. The anti-apoptotic effects of the mixed $\mathrm{ET}_{\mathrm{A}} / \mathrm{ET}_{\mathrm{B}}$ receptor antagonist in our study and that conducted by SHAw et al. [31] have to be observed against the backdrop of the cell-type-specific proapoptotic or anti-apoptotic actions of ET-1 and the relative expression of $\mathrm{ET}_{\mathrm{A}}$ and $\mathrm{ET}_{\mathrm{B}}$ receptors [11]. It is possible that ET-1 signalling promotes apoptosis in pulmonary parenchyma via both $\mathrm{ET}_{\mathrm{A}}$ and $\mathrm{ET}_{\mathrm{B}}$ receptors.

The inhibition of MMP-2 and MMP-9 activities by ET-1 receptor antagonists resulted in a marked attenuation of the enlargement of alveolar airspaces and the destruction of pulmonary parenchyma in the emphysematous rats. It is well known that MMP family members are associated with the degradation of elastin in the alveolar walls and other extracellular matrix components, resulting in the destruction of parenchyma and emphysematous changes [4]. Mouse metalloelastase knock-out studies have implicated this metalloelastase enzyme as a key mediator in the pathology associated with cigarette smoke-induced emphysema [32]. FELX et al. [33] reported that ET-1 promoted the induction of MMP-2 and MMP-9 in human osteosarcoma. Consistently, EBIHARA et al. [34] demonstrated that the $\mathrm{ET}_{\mathrm{A}}$ receptor antagonist had a beneficial effect on glomerular MMP-2 mRNA levels and inhibited tissue MMP in aminonucleoside nephrosis. Our findings strongly suggest that ET-1 may be involved in the enhancement of MMPs in the pathogenesis of pulmonary emphysema.

The CSE injection of rats caused increases of TNF- $\alpha$ and IL-1 $\beta$ levels in the emphysematous lungs and intervention with the ET-1 receptor antagonists prevented this increase. The cytokine increase was accompanied by increased parenchyma apoptosis, MMP-2 and MMP-9 activation in the lung, and decreased serum antioxidant activity. ET-1 is a pro-inflammatory peptide that can stimulate neutrophils and monocytes to release a variety of cytokines [35]; in the meantime, neutrophil elastase also induces ET secretion. TNF- $\alpha$ and IL-1 $\beta$ drive inflammation, and polymorphonuclear leukocytes as well as macrophages produce MMP. Thus, reduction of the inflammatory cytokines, e.g. TNF- $\alpha$ and IL-1 $\beta$, may dampen the inflammation contributing to the development of COPD [10].

The serum antioxidant activity was significantly decreased in CSE-challenged rats; however, ET-1 receptor antagonists were capable of blocking such decrease. Currently, all available evidence related to COPD mechanisms firmly suggests that oxidative stress plays a significant role in the pathogenesis of COPD [6]. ET-1 stimulates the production of superoxide via NADPH oxidase activation, and, conversely, reactive oxygen species appear to stimulate ET-1 production [36]. The prevention of decrease in antioxidant activity upon intervention with ET-1 receptor antagonists suggests that ET-1 is involved in the pathophysiological pathway of oxidative stress in the development of emphysema.

In summary, ET-1 signalling is involved in the pathogenesis of CSE-induced emphysema in rats, resulting in apoptosis, MMP activation, inflammation and oxidative stress. ET-1 is probably part of the upstream pathway in the pathogenesis of emphysema. Further studies are needed to address whether the anti-inflammatory or antioxidant action, or both, are responsible for the apoptosis-protecting effect achieved by the ET-1 receptor antagonists; thus, there are interacting signalling pathways among apoptosis, inflammation and oxidative stress in the pathogenesis of emphysema.

\section{SUPPORT STATEMENT}

This study was supported by the Grant-in-Aid for Scientific Research (C), No. 19590887 from the Japan Society for the Promotion of Science, Japan-China Sasakawa Medical Fellowship (Tokyo, Japan), and the Victoria Johnson Center for Obstructive Lung Disease Research (Richmond, VA, USA).

\section{STATEMENT OF INTEREST}

None declared.

\section{ACKNOWLEDGEMENTS}

The authors thank H. Imamura (Shinshu University School of Medicine, Matsumoto, Japan) for her valuable technical assistance.

\section{REFERENCES}

1 Yoshida T, Tuder RM. Pathobiology of cigarette smoke-induced chronic obstructive pulmonary disease. Physiol Rev 2007; 87: 1047-1082.

2 World Health Organization. The world health report 2002 Reducing risks, promoting healthy life. www.who.int/whr/2002/ en/ Last updated: October 2008; Last accessed: October 2008.

3 Demedts IK, Demoor T, Bracke KR, et al. Role of apoptosis in the pathogenesis of COPD and pulmonary emphysema. Respir Res 2006; 7: 53-63.

4 Pardo A, Selman M. Proteinase-antiproteinase imbalance in the pathogenesis of emphysema: the role of metalloproteinases in lung damage. Histol Histopathol 1999; 14: 227-233.

5 Chung KF, Adcock IM. Multifaceted mechanisms in COPD: inflammation, immunity, and tissue repair and destruction. Eur Respir J 2008; 31: 1334-1356.

6 Tuder RM, Zhen L, Cho CY, et al. Oxidative stress and apoptosis interact and cause emphysema due to vascular endothelial growth factor receptor blockade. Am J Respir Cell Mol Biol 2003; 29: 88-97.

7 Galie N, Manes A, Branzi A. The endothelin system in pulmonary arterial hypertension. Cardiovasc Res 2004; 61: 227-237.

8 Wu-Wong JR, Chiou WJ, Magnuson SR, et al. Endothelin receptor agonists and antagonists exhibit different dissociation characteristics. Biochim Biophys Acta 1994; 1224: 288-294.

9 Wedgwood S, Dettman RW, Black SM. ET-1 stimulates pulmonary arterial smooth muscle cell proliferation via induction of reactive oxygen species. Am J Physiol Lung Cell Mol Physiol 2001; 281: L1058-L1067. 
10 Finsnes F, Skjonsberg $\mathrm{OH}$, Tonnessen $\mathrm{T}$, et al. Endothelin production and effects of endothelin antagonism during experimental airway inflammation. Am J Respir Crit Care Med 1997; 155: 1404-1412.

11 Filippatos GS, Gangopadhyay N, Lalude O, et al. Regulation of apoptosis by vasoactive peptides. Am J Physiol Lung Cell Mol Physiol 2001; 281: L749-L761.

12 Ren A, Yan X, Lu H, et al. Antagonism of endothelin-1 inhibits hypoxia-induced apoptosis in cardiomyocytes. Can J Physiol Pharmacol 2008; 86: 536-540.

13 McWhinnie R, Pechkovsky DV, Zhou D, et al. Endothelin-1 induces hypertrophy and inhibits apoptosis in human airway smooth muscle cells. Am J Physiol Lung Cell Mol Physiol 2007; 292: L278-L286.

14 Hay DW, Henry PJ, Goldie RG. Endothelin and the respiratory system. Trends Pharmacol Sci 1993; 14: 29-32.

15 Hay DW. Putative mediator role of endothelin-1 in asthma and other lung diseases. Clin Exp Pharmacol Physiol 1999; 26: 168-171.

16 Spiropoulos K, Trakada G, Nikolaou E, et al. Endothelin-1 levels in the pathophysiology of chronic obstructive pulmonary disease and bronchial asthma. Respir Med 2003; 97: 983-989.

17 Wright JL, Tai H, Churg A. Vasoactive mediators and pulmonary hypertension after cigarette smoke exposure in the guinea pig. $J$ Appl Physiol 2006; 100: 672-678.

18 Hocher B, Schwarz A, Fagan KA, et al. Pulmonary fibrosis and chronic lung inflammation in ET-1 transgenic mice. Am J Respir Cell Mol Biol 2000; 23: 19-26.

19 Opitz CF, Ewert R, Kirch W, et al. Inhibition of endothelin receptors in the treatment of pulmonary arterial hypertension: does selectivity matter? Eur Heart J 2008; 29: 1936-1948.

20 Chen Y, Hanaoka M, Chen P, et al. Protective effect of beraprost sodium, a stable prostacyclin analog, in the development of cigarette smoke extract-induced emphysema. Am J Physiol Lung Cell Mol Physiol 2009; 296: L648-L656.

21 Brochu I, Labonte J, Bkaily G, et al. Role of endothelin receptors in the hypertensive state of kinin $B_{2}$ knockout mice subjected to a high-salt diet. Clin Sci (Lond) 2002; 103: Suppl. 48, 380S-384S.

22 Landgraf RG, Jancar S. Endothelin A receptor antagonist modulates lymphocyte and eosinophil infiltration, hyperreactivity and mucus in murine asthma. Int Immunopharmacol 2008; 8: 1748-1753.

23 Gamze K, Mehmet HM, Deveci F, et al. Effect of bosentan on the production of proinflammatory cytokines in a rat model of emphysema. Exp Mol Med 2007; 39: 614-620.
24 Bonvallet ST, Zamora MR, Hasunuma $\mathrm{K}$, et al. BQ123, an $\mathrm{ET}_{\mathrm{A}^{-}}$ receptor antagonist, attenuates hypoxic pulmonary hypertension in rats. Am J Physiol 1994; 266: H1327-H1331.

25 Jiang J, Yuen V, Xiang H, et al. Improvement in cardiac function of diabetic rats by bosentan is not associated with changes in the activation of PKC isoforms. Mol Cell Biochem 2006; 282: 177-185.

26 Uhlmann D, Armann B, Gaebel G, et al. Endothelin A receptor blockade reduces hepatic ischemia/reperfusion injury after warm ischemia in a pig model. J Gastrointest Surg 2003; 7: 331-339.

27 Taraseviciene-Stewart L, Nicolls, Burns N, et al. Intraperitoneal injection of cigarette smoke extract causes lung cell death and emphysema in rats. Am J Respir Crit Care Med 2006; 173: A626.

28 Taraseviciene-Stewart L, Kraskauskas D, Lee JH, et al. Cigarette smoke extract (CSE)-induced emphysema in mice. Am J Respir Crit Care Med 2007; 175: A529.

29 Taraseviciene-Stewart L, Burns N, Kraskauskas D, et al. Mechanisms of autoimmune emphysema. Proc Am Thorac Soc 2006; 3: 486-487.

30 Agusti A, MacNee W, Donaldson K, et al. Hypothesis: does COPD have an autoimmune component? Thorax 2003; 58: 832-834.

31 Shaw MJ, Shennib H, Tayara L, et al. Endothelin receptor antagonist SB209670 decreases lung allograft apoptosis and improves lung graft function after prolonged ischemia. $J$ Cardiovasc Pharmacol 2000; 36: S209-S211.

32 Belvisi MG, Bottomley KM. The role of matrix metalloproteinases (MMPs) in the pathophysiology of chronic obstructive pulmonary disease (COPD): a therapeutic role for inhibitors of MMPs? Inflamm Res 2003; 52: 95-100.

33 Felx M, Guyot MC, Isler M, et al. Endothelin-1 (ET-1) promotes MMP-2 and MMP-9 induction involving the transcription factor NF-кB in human osteosarcoma. Clin Sci (Lond) 2006; 110: 645-654.

34 Ebihara I, Nakamura T, Tomino Y, et al. Effect of a specific endothelin receptor A antagonist and an angiotensin-converting enzyme inhibitor on glomerular mRNA levels for extracellular matrix components, metalloproteinases (MMP) and a tissue inhibitor of MMP in aminonucleoside nephrosis. Nephrol Dial Transplant 1997; 12: 1001-1006.

35 McMillen MA, Sumpio BE. Endothelins: polyfunctional cytokines. J Am Coll Surg 1995; 180: 621-637.

36 Duda M, Konior A, Klemenska E, et al. Preconditioning protects endothelium by preventing ET-1-induced activation of NADPH oxidase and xanthine oxidase in post-ischemic heart. J Mol Cell Cardiol 2007; 42: 400-410. 